\title{
Student misconceptions about plant transport - a Sri Lankan example
}

\author{
P.R.K.A. Vitharana \\ Department of Education, University of Peradeniya, Kandy, Sri Lanka. \\ For correspondence: pushpa.vitharana@yahoo.com
}

\begin{abstract}
Students bring with them their own misconceptions to the science classes and it becomes a barrier in developing new concepts. Therefore, identifying misconceptions is an essential component in teaching science. The objective of this study was to identify $10^{\text {th }}$ grade students' misconceptions on plant transport with the use of two-tier diagnostic test. The development procedure of the two-tier diagnostic test had three steps; (i) defining the content boundaries of the test (ii) collecting information on student misconceptions and (iii) instrument development. Student alternative conceptions were collected after interviewing 25 students and multiple choice questions with free responses being administered to the students. With the use of the date obtained, sixteen (08) two-tier multiple test items were constructed. The first tier examined the content knowledge and the second tier the reasons for the content. The conceptual knowledge examined in the test items were water absorption, mineral salt absorption, transportation of water, transpiration, organic food transportation. The diagnostic test was administered to $180,10^{\text {th }}$ grade students. It was revealed that students possessed 18 misconceptions. The highest number of misconceptions was recorded in the areas of organic food transportation and the transpiration. The most common misconception was found in the area of organic food transportation.
\end{abstract}

Keywords: Misconceptions; Two-tier test; Plant transport

\section{Introduction}

Learning is a complex process in which a learner constructs new knowledge. According to Benbow and Mably (2002) learners' minds are not simply empty spaces waiting to be filled since they bring their prior learning to that moment. As they further explain this is more crucial in learning science because of the complex nature of ideas and concepts. Duit and Treagust (2003) emphasize that, majority of students come to science classes with a knowledge or beliefs about the phenomena to be taught and many students develop only a limited understanding of science concepts after instruction. As Treagust (1995) further explains students construct understanding of phenomena and concepts as seen through their own eyes that do not match with the scientifically accepted views. Researches conducted in Science Education have demonstrated that students possess their own conceptions of natural phenomena (Treagust, 1995; Osborne, 1985; Skamp. 1998).

Student conceptions that are different from scientists have been given numerous terms as misconceptions (Odom and Barrow, 1995) preconceptions, alternative framework, children's science (Treagust, 1995) preconceived notions, naïve theories (Anderson, and smith, 1985) and informal ideas (Benbow and Mably, 2002). Numerous research studies have reported students' alternative conceptions on a range of science concepts e. g. electric current and animals (Osborne, 1985) qualitative analysis (Tan, et al., 2002) photosynthesis and respiration (Treagust and Haslam, 1986) plant transports and human circulation (Wang, 2004) diffusion and osmosis (Odom and Barrow,1995). 
Researchers in the field of science education state that students' misconceptions are strongly held and are resistant to change (Driver,1983;Yip, 1998; Treagust, 1995; Tekkaya, 2003).

When students possess misconceptions at any level, the teachers' role is crucial as it is needed to eliminate misconceptions of students. Otherwise, the students would become alien to them being unable to assimilate new knowledge into their existing level. Therefore, teachers need to know ideas of scientists about the concepts to be taught as well as the misconceptions of students in order to promote effective science teaching. The importance of identifying misconceptions has been emphasized on many occasions in literature. According to Osborne (1985), Staver (2007), Selley (1999) and Ross et al., (2000), it is crucial in science teaching to identify misconceptions or alternative conceptions of students. Yip (1998) explains identifying misconceptions as an initial step in science teaching. The role of science teacher is to find out student misconceptions and guide them towards better understanding through hands-on activities, investigation and interaction with peers and adults. Investigating children's ideas is important for students and teachers (Ross et al., 2000; Duit et al.,1996). It helps teachers to understand existing levels of students and allows the students to compare existing ideas with new ones.

Two-tier test as a diagnostic instrument has been widely used to identify student misconceptions on biological science concepts (Treagust and Haslam, 1987; Wang, 2004; Odom and Barrow, 1995). Naturalistic Settings ( Duit et al., 1996; Ollerenshaw and Ritchie, 1993; Tuysuz, 2004), interviews (Tregust et al., 1996; Bell , 1995; Ross et al., 2000), concept maps ( Duit et al., 1996; Toysuz, 2009; Selley , 1999; Harlen, 1992), diagnostic test items (Treagust and Haslam,1986; Wang,2004; Odom and Barrow, 1995; Tan, et al., 2002), whole class and group discussions, (Ollerenshaw and Ritchie, 1993) students' drawing, writing and annotations (Ross et al., 2000; Harlen,1992)have been reported as methods to identify student misconceptions in learning science. However none of the research has been conducted in Sri Lanka with the use of two-tier diagnostic test to identify student misconceptions.

Treagust (1995) describes two tier-test as an instrument having items with two tiers to diagnose student understanding in a particular content area of science. As he further explains, the first part of each item on the instrument is a multiple choice content question with usually two or three choices. The second part of each item contains a set of four possible reasons for the answer given to the first part consisting of the correct answer together with incorrect conceptions. The objective of this study was to identify $10^{\text {th }}$ grade students' misconceptions on Plant Transport with the use of a two-tier diagnostic test.

\section{Method}

The study consisted of two main phases; constructing the two-tier test and implementing the test. The design of the diagnostic instrument was based on the procedure described by Treagust (1995) that included three broad phases: (a) defining the content in terms of propositional knowledge statements and concept map for the specified concept (b) obtaining information about students' conceptions and (c) developing a diagnostic instrument. In the two-tier diagnostic instrument, the first tier of each item in the test is a multiple choice content question providing several distracters along with the correct answer, The second tier is composed of a multiple choice set of reasons for the answer to the first tier. The reasons provided for students contain the correct answer and possible misconceptions identified in questionnaires and interviews.

\section{Defining the content}

18 propositional knowledge statements given below were identified by reviewing the grade 10 science syllabus, teacher instructional manual and text books. A concept map for plant transport system was developed (Figure 1) according to the content of grade ten syllabus. Propositional knowledge 
statements were content validated by three experienced science graduate teachers. Discrepancies identified in the test items were corrected and modified.

1. Plants absorb water through root hair cells.

2. Water inside the root hair cells has much higher solute concentration than that in the soil.

3. Water moves into the root hair cells by osmosis.

4. Active transport is the movement of particles from cells to the outside or outside to the cells against concentration gradient.

5. Active transport occurs with the help of energy released due to metabolic activities.

6. Mineral irons actively transport through root hairs.

7. Water and mineral salts are absorbed through root hair and transport to various parts of the plant through xylem.

8. The water molecules are strongly attracted to each other. This is called cohesion

9. Cohesion occurs as a result of attraction between water molecules and the wall of the vessel.

10. The pressure exerted by the root system of a plant to move water up in the xylem vessels is called root pressure.

11. Transpiration is the loss of water vapour from the aerial parts of the plant. And it mainly occurs through stomata.

12. The evaporation of water from the top of the plant creates a pulling force drawing the water up the xylem and it is called transpiration pull.

13. Light, temperature, wind and humidity affect rate of transpiration.

14. The rate of transpiration is inversely proportional to humidity and it is directly proportional to light, temperature and wind

15. The food made by leaves transports to all the parts of the plants through phloem.

16. The movement of food can be upward as well as downward depending upon the needs of a plant.

17. The movement of food through phloem occurs due to mass flow

18. Mass flow is the movement of materials as a bulk from one place to another due to pressure change. 


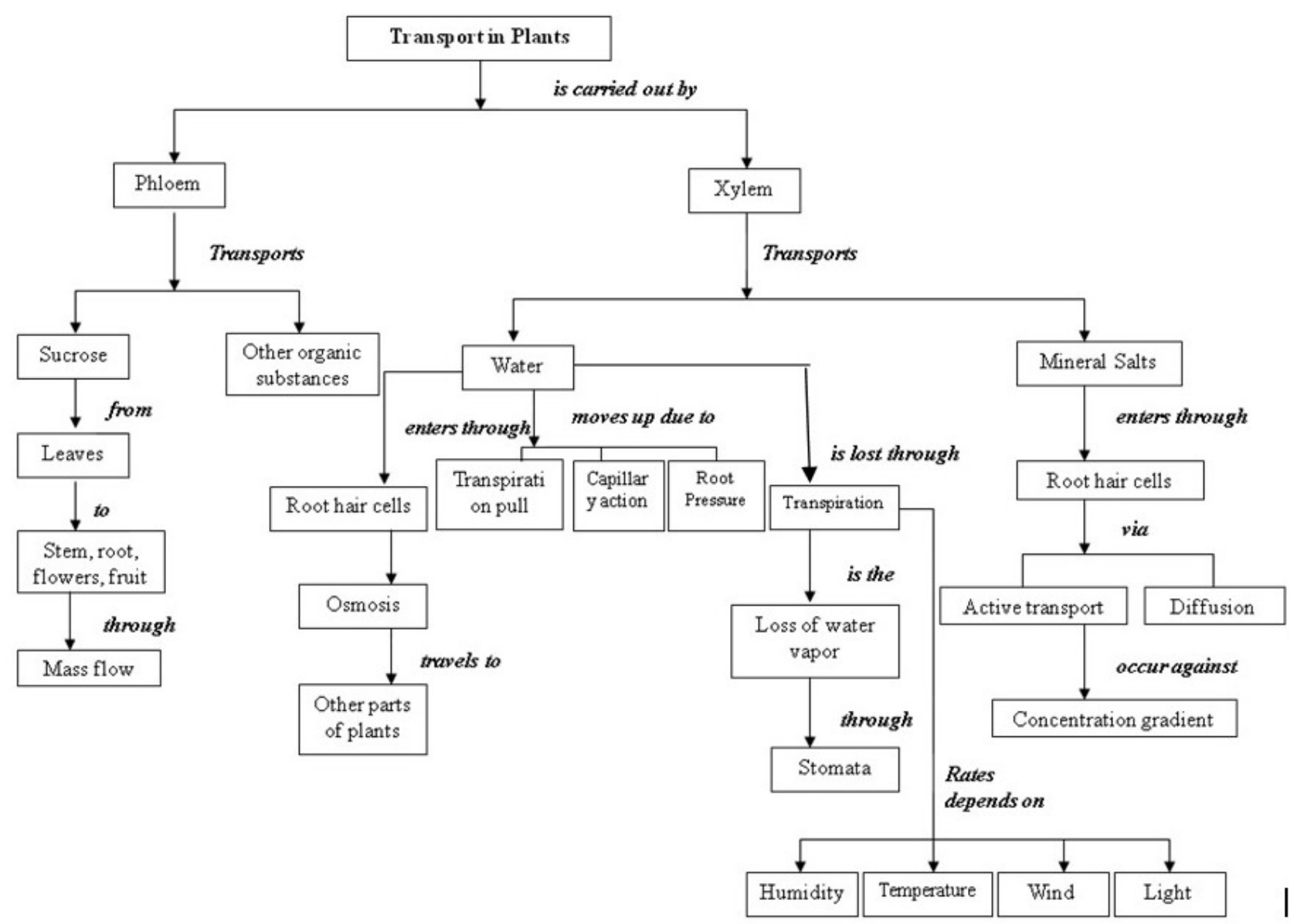

Figure 1. Concept map of plant transport

Obtaining information about students conceptions

The findings of the research conducted by Odom and Borrow (1995) to identify misconceptions of Osmosis and Diffusion and the research conducted by Wang (2004) to identify misconceptions of Plant transport and Human circulation were examined in constructing multiple choice items. In the next step of the research unstructured interviews were conducted with 25 grade 10 students in order to gain a broad perspective of students' understanding of plant transport. All the interviews were audiotape recorded and interview transcripts were prepared for each interview. Examples of openended questions used in interviews are, "How does a plant obtain water"? A list of students misconceptions were prepared by examining interview transcripts.

The next step which I followed was developing multiple choice items with free responses. Each multiple choice item was based on limited number of propositional knowledge statements. Multiple choice items were designed to address students' conceptions and misconceptions encountered in the literature and the interview. Each item was followed by a space for the student to complete the reason why particular option of the multiple choices was selected. Open-ended multiple choice test instrument was administered to 25 students and the free responses were examined to collect misconceptions of plant transport.

\section{Construction of Two-Tier diagnostic instrument}

Based on the collected group of misconceptions obtained from each item in the multiple choice test with free responses and interviews a two-tier diagnostic instrument was constructed. Each test item in the instrument consisted of a stem followed by two-tier questions. The first tier of each item 
provided a selection of possible distractions related to the students' misconceptions in addition to the correct answer. The second tier consisted of four possible reasons for the first tier: three alternative reasons and one scientifically accepted reason. A pilot study was conducted to refine the item on the diagnostic text. The final version of the test consisted of 08 items. The content area addressed by each question and the relevant propositional statement is given in Table 1.

Table 1. The content area and the relevant propositional statement in each of the test item

\begin{tabular}{cll}
\hline $\begin{array}{c}\text { Item } \\
\text { Number }\end{array}$ & Topic Area & $\begin{array}{l}\text { Propositional } \\
\text { statement }\end{array}$ \\
\hline 1 & Water absorption & $1,2,3$ \\
2 & Mineral salt absorption & $4,5,6,7$ \\
3 & Transportation of water & $8,9,10$ \\
4 & Transportation of water & 10,12 \\
5 & Transpiration & 11 \\
6 & Transpiration & 13,14 \\
7 & Organic food transportation & 15,16 \\
8 & Organic food transportation & 17,18
\end{tabular}

Sample of population

The plant transport diagnostic test was administered to 180 grade ten students after instruction. The convenience sampling was used in this research and total number of 6 schools three from Kandy district and three from Kegalle district were selected.

Scoring the items and analysis of responses

An item was scored as correct on the two-tier diagnostic test when both the tiers (content and reason) were selected, and students were offered two marks for each item. As there were 08 items students were given marks out of 16 for the whole test. Percentage of students selecting each response combination was calculated in all 08 items as an example shown below. (Table 2)

Table 2 . Percentage of students responses to item no.1

\begin{tabular}{llllllll}
\hline Item & $\begin{array}{l}\text { Content } \\
\text { choice }\end{array}$ & \multicolumn{5}{c}{ Reason choice } & Total \\
\cline { 3 - 7 } & & $\mathrm{a}$ & $\mathrm{b}$ & $\mathrm{c}$ & $\mathrm{d}$ & \multicolumn{2}{l}{$\begin{array}{l}\text { No } \\
\text { reason }\end{array}$} \\
\hline$(1)$ & $\mathrm{a}$ & 21.1 & ${ }^{*} 14.4$ & 5.6 & 6.1 & 1.1 & 48.3 \\
& $\mathrm{~b}$ & 7.8 & 8.9 & 9.4 & 7.2 & 1.1 & 34.4 \\
& $\mathrm{c}$ & 4.4 & 5.0 & 6.7 & 0.5 & 0.5 & 17.1 \\
\end{tabular}

* the correct content choice and reason response

Question No. 1 was

(1a). The process responsible for absorption of water by root hair of plants is
a. Osmosis
b. Active transport
c. Diffusion

(1b) The reason for my answer is because 
a. Concentration of cell sap is lower than that of soil water

b. Concentration of cell sap is higher than that of soil water

c. Movement of water molecules spending energy, opposing to diffusion

d. Water concentration of soil particles is lower than water concentration of root hair cell.

\section{Results and discussion}

The characteristics of Plant Transport System Diagnostic Test (Annex 01) summarizes in Table 3.

Table 3. Characteristics of the Plant Transport and Human Circulatory System diagnostics test

$\begin{array}{ll}\text { Areas evaluated : } & \text { Water absorption: item,1 } \\ & \text { Mineral salt absorption: item 2 } \\ & \text { Transportation of water: items 3, } 4 \\ & \text { Transpiration: items 5, 6 } \\ & \text { Organic food transportation: item 7, } 8\end{array}$

Content based on: Validated propositional knowledge statements and concept map

Number of items: 06

Recommended grade level: $10^{\text {th }}$ grade (Grade 10 )

Time to complete test: $15-20$ minutes

Percentage of students with correct content choice and combination: content and reason are given in Table 4.

Table 4 Percentage of students selecting the correct content and combination

\begin{tabular}{ccc}
\hline Item & Content Choice & Combination \\
\hline 1 & 48.3 & 14.4 \\
2 & 51.1 & 38.8 \\
3 & 42.2 & 36.1 \\
4 & 67.2 & 30.5 \\
5 & 81.6 & 59.4 \\
6 & 75.5 & 28.3 \\
7 & 59.4 & 29.4 \\
8 & 82.2 & 32.4 \\
\hline
\end{tabular}

The range of correct answers for the first tier varied from $42.2 \%$ to $82.2 \%$ where as combination varied from $14.4 \%$ to $59.4 \%$. When the first-tier of the items only is taken into consideration the results show that there is generally high percentage of correct response choice exceeding $50 \%$ except in two items; item 1 and 3. However when students' reasoning for their choice (combination choice of Table 4) in the first-tier of the item is taken into consideration, the percentage of correct responses are much lower in most of the items.. The highest percentage of correct content choice was recorded from items no. 5 which was based on transpiration. The lowest percentage of correct content was shown in item no. 3 based on uptake of water by roots. There is a considerable difference in the percentages of correct content choice and the combination choice.

Eighteen major misconceptions were identified through analysis of items on the Plant transport diagnostic test (Table 5) 
Table 5. Student misconceptions of plant transport and human circulatory system identified by the two -tiered test

\begin{tabular}{llll}
\hline Item & \multicolumn{1}{c}{ Area } & Misconception' Identified & Percentage \\
\hline (1) & $\begin{array}{l}\text { Water } \\
\text { absorption }\end{array}$ & $\begin{array}{l}\text { The movement of water to the root hair cells occur due } \\
\text { to osmosis since solute concentration in the fluid inside } \\
\text { root hair cells is lesser than in the fluid outside (soil) }\end{array}$ \\
(2) $\quad \begin{array}{l}\text { Mineral } \\
\text { absorption }\end{array}$ & $\begin{array}{l}\text { Absorption of mineral irons in plants occur due to 22.7 } \\
\text { concentration gradient } \\
\text { Absorption of mineral irons take place through } 11.1 \\
\text { permeable membranes }\end{array}$
\end{tabular}

Absorption of mineral irons occur due to osmosis since 9.4 it is to according to concentration gradient

(3) Transportation A continuous water column maintains in xylem vessels of water in a tall plant due to the force exerted by root system

A continuous water column maintains in the xylem 32.7 vessels due to lose of water vapor from plants

(4) Transportation Transportation of water through xylem vessels to of water leaves of a tall plant occur due to transpiration pull since it loses water from leaves and filling vacant places

Transportation of water to the leaves of a tall plant 13.8 through xylem vessels occurs due to continuous upward pressure excreted by roots

(5) Transpiration A person under a large tree in a sunny day feels cool due to transpiration since water vapor releases from different parts of the plant

Transpiration is loss of water vapor from different 13.8 parts of a plant

(6) Transpiration Rate of Transpiration is greater when the humidity is higher since temperature increase in the environment

When the humidity in the environment is higher the 16.1 amount of water vapor in the air becomes limited Rate of transpiration is slower when the humidity is 27.7 higher since temperature decrease in the environment

(7) Organic food Plants obtain organic food by root hairs and transport transportation all parts of plants

Food storage in plants takes place only in the upper 8.3 parts of plants

(8) Organic food The movement of food in phloem tissues takes place transportation due to concentration gradient 
Mass flow occurs due to the movement of materials to 28.8 same direction as a result of gravitational force

Mass flow is the movement of particles to same 35.5 direction due to pressure changes

As shown in Table 5 students had misconceptions related to each item of the diagnostic test. The first two questions were based on absorption of water and mineral irons. In considering the first question, although students selected osmosis as the correct content choice, $21.1 \%$ of them had misconception regarding the solute concentration in the cells of root hairs. Students had several misconceptions in understanding movement of mineral irons.

A considerable percentage of students $21.1 \%$ and $32.7 \%$ showed misconceptions in question no 3 which was based on transportation of water through xylem vessels. They were in the view that root system provides an enough force to maintain a continuous water column. The next two questions were based on transpiration. More than $10 \%$ of students showed each misconception in the process of transpiration. The most common misconceptions were identified from the sub areas organic food transportation and transportation of water. Out of those $35.5 \%$ students had misconception in obtaining organic food.

\section{Absorption of water and Minerals}

Item 1 and 2 examined students' understanding of water and mineral absorption respectively. Responses of each item were analyzed as shown in Table 6.

Table 6. Percentage of students responses to item no.1 and 2

\begin{tabular}{|c|c|c|c|c|c|c|c|}
\hline \multirow[t]{2}{*}{ Item } & \multirow{2}{*}{$\begin{array}{l}\text { Content } \\
\text { choice }\end{array}$} & \multicolumn{5}{|c|}{ Reason choice } & \multirow[t]{2}{*}{ Total } \\
\hline & & a & $\mathrm{b}$ & $\mathrm{c}$ & $\mathrm{d}$ & $\begin{array}{l}\text { No } \\
\text { reason }\end{array}$ & \\
\hline \multirow[t]{3}{*}{ (1) } & a & 21.1 & *14.4 & 5.6 & 6.1 & 1.1 & 48.3 \\
\hline & b & 7.8 & 8.9 & 9.4 & 7.2 & 1.1 & 34.4 \\
\hline & c & 4.4 & 5.0 & 6.7 & 0.5 & 0.5 & 17.1 \\
\hline \multirow[t]{4}{*}{ (2) } & a & 6.1 & 8.3 & 7.2 & 5.6 & 1.7 & 28.6 \\
\hline & $\mathrm{b}$ & 1.1 & - & 1.1 & 0.5 & - & 2.7 \\
\hline & c & 6.1 & $* 38.9$ & 3.3 & 2.7 & - & 51.0 \\
\hline & d & 9.4 & 4.4 & 0.5 & 2.2 & - & 16.5 \\
\hline
\end{tabular}

*the correct choice and reason response

- No response in this category

Four major misconceptions were identified from these two items. Out of these four misconceptions three were related to mineral salt absorption. According to the percentage of reason choice, it was clear that reasonable percentage of students had misconceptions regarding solute concentration of root hair cells. Nearly fifty percent of students (48.3\%) have understood osmosis as the mechanism of water absorption while 34.4 and 17.1 responded active transport and diffusion as the correct content choice. During interview with students, they provided all three mechanisms osmosis, active transport and diffusion but most of the students were not confident in explaining mechanism. When the first part of the item only is taken into consideration in item 2 the results show that more than $15 \%$ 
students (16.5\%) in the view that osmosis as the mechanism of mineral salt absorption and $28.6 \%$ mass flow as the mechanism.

Transportation of water

This concept was assessed through items 3 and 4. Analyses of responses for these two are shows in Table 7.

Table 7. Percentage of students responses to item no. 3 and 4

\begin{tabular}{|c|c|c|c|c|c|c|c|}
\hline \multirow{2}{*}{ Item } & \multirow{2}{*}{$\begin{array}{l}\text { Content } \\
\text { choice }\end{array}$} & \multicolumn{5}{|c|}{ Reason choice } & \multirow{2}{*}{ Total } \\
\hline & & $\mathrm{a}$ & b & c & d & $\begin{array}{l}\text { No } \\
\text { reason }\end{array}$ & \\
\hline \multirow[t]{3}{*}{ (3) } & a & 2.8 & 16.1 & - & 1.7 & - & 20.6 \\
\hline & b & 27.2 & 1.7 & 7.2 & 0.6 & - & 37.2 \\
\hline & c & 2.7 & 3.3 & - & $* 36.1$ & - & 42.2 \\
\hline \multirow[t]{3}{*}{ (4) } & a & *30.5 & 1.6 & 5.0 & 28.9 & 0.2 & 67.2 \\
\hline & b & 5.5 & 2.8 & 6.1 & 2.8 & 0.5 & 17.7 \\
\hline & c & 6.1 & 1.1 & 2.8 & 3.9 & 1.1 & 15.0 \\
\hline
\end{tabular}

*the correct choice and reason response

- No response in this category

Three misconceptions were identified from these two items. Nearly $60 \%$ of students were unaware of the role of adhesion and cohesion forces of water to maintain continuous water column. A considerable number of students were in the view that transpiration only contribute to maintain continuous water column in xylem vessels. Question no. 4 was addressed to ascertain students understanding on transpiration pull. Although high percentage of them (67.2\%) selected correct content choice they were incapable of selecting correct reason. Although students responded root pressure as the correct content but it is only for shorter plants. Students have not paid their attention on the word "higher" in the stem of question. However students those who selected root pressure without considering higher plants were unable to respond the correct reason.

\section{Transpiration}

Transpiration concept was examined through items 5 and 6 . The result of the students responses to these questions are given in Table 8.

Table 8. Percentage of students responses item no.5 and 6

\begin{tabular}{cccccccc}
\hline \multirow{2}{*}{ Item } & $\begin{array}{c}\text { Content } \\
\text { choice }\end{array}$ & \multicolumn{9}{c}{ Reason choice } & Total \\
\cline { 3 - 7 } & & $\mathrm{a}$ & $\mathrm{b}$ & $\mathrm{c}$ & $\mathrm{d}$ & $\begin{array}{c}\text { No } \\
\text { reason }\end{array}$ & \\
\hline \multirow{2}{*}{$(5)$} & $\mathrm{a}$ & 3.9 & 13.9 & 3.3 & $* 59.4$ & 1.1 & 81.6 \\
& $\mathrm{~b}$ & 1.7 & 1.1 & 1.1 & 0.5 & - & 4.4 \\
& $\mathrm{c}$ & - & 6.1 & 0.5 & 7.2 & - & 13.8 \\
$(6)$ & $\mathrm{a}$ & 1.1 & 2.2 & 16.6 & 3.8 & 0.1 & 24.4 \\
& $\mathrm{~b}$ & $* 28.3$ & 13.9 & 5.0 & 27.8 & 0.5 & 75.5 \\
\hline
\end{tabular}

*the correct choice and reason response

- No response in this category

In considering item no. 5, 81.6\% students selected the correct content choice however more than $10 \%$ of students (13.9) responded reason choice as "releases of water vapor from different parts of the 
plant". They have not understood transpiration as the loss of water vapor from aerial parts of plants. Item no. 6 was change of rate of transpiration when the humidity of the environment increases. The desired response combination was "Rate of transpiration decreases because the amount of water vapor increases in the environment" A minority of students $(28 \%)$ selected the desired answer combination. The most common misconception was rate of transpiration decreases when the humidity increases because temperature of the environment decrease with increasing humidity

Transportation of organic food

Item 7 and 8 examined students understanding of route of organic food. The analysis of students responses to these two questions are given in Table 9.

Table 9. Percentage of students responses item no. 7 and 8

\begin{tabular}{cccccccc}
\hline Item & $\begin{array}{c}\text { Content } \\
\text { choice }\end{array}$ & \multicolumn{7}{c}{ Reason choice } & Total \\
\cline { 3 - 7 } & & & $\mathrm{b}$ & $\mathrm{c}$ & $\mathrm{d}$ & $\begin{array}{c}\text { No } \\
\text { reason }\end{array}$ \\
\hline 7 & $\mathrm{a}$ & 2.2 & 1.1 & 18.8 & 3.8 & - & 25.5 \\
& $\mathrm{~b}$ & 3.9 & 1.7 & 2.8 & 3.8 & - & 12.2 \\
& $\mathrm{c}$ & $* 29.4$ & 15.0 & 13.9 & 1.1 & - & 59.4 \\
8 & $\mathrm{a}$ & 4.4 & 25.6 & 16.7 & $* 32.8$ & 2.7 & 82.2 \\
& $\mathrm{~b}$ & 2.7 & 1.7 & 1.7 & 1.1 & 0.5 & 7.7 \\
& $\mathrm{c}$ & 1.1 & 1.6 & 1.7 & 3.3 & - & 7.7 \\
\hline
\end{tabular}

*the correct choice and reason response

- No response in this category

In item 7 the direction of the water transport was addressed. The most common misconception was the "Movement of food only to upward because organic food obtains through root hairs of a plant" $(18.8 \%)$. Out of the students selected correct content choice $15 \%$ were in the view that food storage of plants occur that upper and lower parts of plants. A total of $35.5 \%$ of students had the misconception "Plants absorb organic food through root hairs and transport to different parts of plants" students may have misunderstood this as the water and mineral salt absorption from food the soil. Item 8 was based on the mechanism required for food transportation through phloem. More than $80 \%$ of students $(82.2 \%)$ selected the desired content choice mass flow however only $32.8 \%$ of students selected the correct reason.

\section{Conclusions}

This study provides evidence that grade ten students have several misconceptions of plant transport. The results show that high percentages of students are capable of selecting only the correct content choice not the combination (content and reason). It is evident that students learn the content without understanding concepts in plant transport. The analysis of students responses reveals that students do not have a correct conceptual understanding of mechanisms responsible for plant transport especially osmosis, diffusion, active transport and transpiration. The results of the study were supported by other studies in the literature (Odom an Barrow, 1995 and Wang, 2004)

The results of the study showed that the two-tier diagnostic test was on effective instrument for assessing students' understanding and for diagnosing students' misconceptions. Literature review supported the results (Treagust and Haslam, 1986, Chen et al., 2002 ; Tuysuz, 2009; Chen and Lin,2002). 


\section{Implication for teaching}

Teachers need to identify students' misconceptions of any science topic in the teaching learning process. The understanding of misconceptions is essential to develop strategies to avoid misconceptions of and promote accurate conceptual understanding of concepts and phenomena.

\section{Acknowledgements}

The study was financially supported by the University of Peradeniya, Sri Lanka.

\section{References}

Anderson, C.W. \& Smith, E.L. (1985). In The educator's handbook: A research Perspective. Teaching Science, Koehler, V. (ed). New York: Longman.

Bell, B. (1995). Interviewing : A technique for assessing science knowledge. Glynn, S. M. \& Duit, R. (eds). New Jersey: Lawrence Erlbaum Associates Publishers.

Benbow, A. \& Mably, C. (2002). Science education for elementary teachers. USA: Wadsworth Thomson Learning.

Driver, R. (1983) The pupil as scientist, Philadelphia: Open University press.

Duit, R., Treagust, D. F. \& Mansifield, H. (1996). Investigating students' understanding as a prerequisite to improving teaching and learning in science and mathematics. In Improving teaching and learning in science and mathematics. Treagust, D. F. , Duit, R. \&fraser, B. J. (eds). New York: Teachers College Press.

Duit, R. and Treaguat, D. F. (2003). Conceptual change: a powerful framework for improving science teaching and learning, International Journal of Science education, 25(6), 671-688.

Harlen, W. (1992). The teaching of science, London: David Fulton publishers.

Odom, A. L. \& Barrow, L.H. (1995). Development and application of a two-tier diagnostic test measuring college biology students' understanding of diffusion and osmosis after a course of instruction. Journal of Research in Science Teaching, Vol. 32, No.1, 45-61

Ollerenshaw, C. \& Ritchie, R. (1993). Primary science making it work, London: David Fulton Publishers.

Osborne, R. (1985). Children's own concepts. In Primary science: Taking the plunge. W. Harlen. (ed). Pp. 75-91. London: Heinemann Educational.

Ross, K., Lakin, L. \& Callaghan, P. (2000). Teaching secondary science, London: David Fulton Publishers.

Selley, N. J. (1999). The art of constructivist teaching in the primary school, Great Britain: David Fulton Publishers.

Skamp, K. (1998). Ed. Teaching primary science constructively, In Teaching primary science constructively. $2^{\text {nd }}$ ed. Pp.1-43. Australia: Harcourt Australia Ply Ltd.

Staver, J. R. (2007). Teaching science, France: International Bureau of Education

Tan, K.C.D., Goh, N.K., Chia, L.S., treagust, D.F. (2002). Development and application of a two-tier multiple choice diagnostic instrument to assess high school students' understanding of inorganic chemistry qualitative analysis. Journal of Research in Science Teaching, Vol. 39, No.4, 283-301

Tekkaya, C. (2003). Changing students' scientific misconceptions. Research in Science and Technological Education, Vol. 21, No. 1, 5-16.

Treagust, D.F. \& Haslam, F. (1986). Evaluating secondary students' misconceptions of photosynthesis and respiration in plants using a two-tier diagnostic instrument. Paper presented at the $5^{\text {th }}$ annual meeting of the National Association for research in Science teaching, San Francisco, California, March 28-31,

Treagust, D. F. (1995). Diagnostic assessment of students' science knowledge. In Learning science in the schools. Glynn, S. M. \& Duit, R. (eds). New Jersey: Lawrence Erlbaum Associates Publishers.

Tüysüz, C. (2009). Development of two-tier diagnostic instrument and assess students' understanding in chemistry. Scientific Research and Essay Vol. 4(6), 626-631.

Wang, J. (2004) Development and validation of a two-tier instrument to examine understanding of internal transport in plants and the human circulatory system International Journal of Science and Mathematics Education, Vol 2, No, ,2 131-157.

Yip, D. (1998). Identification of misconceptions in novice biology teachers and remedial strategies for improving biology teaching. International Journal of Science Education, Vol.20,No.4, 461-477. 


\section{Annex 01}

\section{Plant Transport Diagnostic Test}

Instruction: This test consists of 08 pairs of questions that examine your knowledge of Plant Transport Each question has two parts: a multiple choice response followed by a multiple choice reason. On the answer sheet provided, please circle one answer from both response and reason sections of each question.

(1) a. The process responsible for absorption of water by root hair of plants is :
a. Osmosis
b. Active transport
c. Diffusion

b. The reason for my answer is because :
a. Concentration of cell sap is lower than that of soil water
b. Concentration of cell sap is higher than that of soil water
c. Movement of water molecules spending energy, opposing to diffusion
d. Water concentration of soil particles is lower than that of root hair cells

(2) a. Mineral salt is essential for growth of a plant. The process responsible for absorption of mineral salt is :
a. Mass flow
b. Diffusion
c. Active transport
d. Osmosis

b. The reason for my answer is because :
a. Absorption occurs due to concentration gradient
b. Absorption occurs with the help of energy opposing to diffusion
c. Movement as a bulk due to pressure changes
d. Absorption through permeable membranes

(3) a. The characteristics of water molecules to maintain a continuous column of water is :
a. Root pressure
b. Transpiration
c. Cohesion - Addison
d. Forces

b. The reason for my answer is because :
a. Releasing water as water vapors
b. A pressure excreted by root through root system
c. Releasing water from tips of leaves as liquid
d. Interaction among water molecules and adsorption of water molecules to walls of xylem vessels

(4) a. Which one of the following process is responsible for carrying water to the leaves of a tall plant through xylem vessels :
a. Transpiration pull
b. Root pressure
c. Absorption through roots 
b. The reason for my answer is :
a. Due to a force of moving water upward through xylem vessels
b. Deficiency of water in the xylem
c. Due to a upward pressure exerted by roots
d. Removal of water from the leaves and fill that deficiency

(5) a. A person under a large tree feels cold. What is the responsible for this :
a. Transpiration
b. Guttation
c. Transpiration and guttation

b. The reason for my answer is :
a. Collection of water in the environment due to removal of water as liquid form
b. Removal of water vapors due to sunlight from different aerial parts of a plant
c. Removal of water from the plant and adding to the environment
d. Adding water molecules to the environment due to removal of water vapors from the leaves

(6) a. When the humidity increases transpiration rate :
a. Increases
b. Decreases

b. The reason for my answer is :
a. Because it increases the water vapor in the environment
b. Because it limits the amount of water vapour in the environment
c. Temperature of the environment increases when the humidity increases
d. Temperature of the environment decreases when the humidity increases

(7) a. Organic food transportation occurs in plants :
a. Only to upward
b. Only to downward
c. upward and downward

b. The reason for my answer is :
a. Movement of organic food produced in the leaves to all parts of a plant
b. Deposition of food in the upper and lower parts of a plant
c. Absorption of organic food through root hair and transportation to all parts
d. Deposition of food in the upper parts

(8) a. Which one of the following phenomena is responsible for transportation of food through phloem tissue :
a. Mass flow
b. Diffusion
c. Osmosis

b. The reason for my answer is :

a. Movement of particles for higher concentration to lower concentration 
b. Movement of particles of a material to one direction due to gravity

c. Movement of particles of a material to direction due to pressure gradient

d. Movement of materials as a bulk due to pressure gradient 